\title{
Seabird Transfer of Nutrients and Trace Elements from the North Water Polynya to Land during the Mid-Holocene Warm Period, Carey Islands, Northwest Greenland
}

\author{
Peter M. Outridge, ${ }^{1}$ Michael E. Goodsite, ${ }^{2}$ Ole Bennike, ${ }^{3}$ Nicole Rausch ${ }^{4}$ and William Shotyk ${ }^{5}$
}

(Received 8 January 2016; accepted in revised form 5 April 2016)

\begin{abstract}
Seabird guano from large nesting colonies is known to increase trace metal levels in adjacent terrestrial environments today, when global oceans are contaminated with $\mathrm{Hg}, \mathrm{Cd}$, and other metals. But the effect of seabird guano in the pre-industrial period has rarely been studied. We used stable $\mathrm{C}$ and $\mathrm{N}$ isotopic and trace element analyses of a peat core that represents ca. 2000 years of organic matter accumulation to examine the effect on trace elements and nutrients of a seabird colony that existed in northern Baffin Bay during the Holocene Thermal Maximum (ca. 8000-5000 yr BP). Although C and N concentrations were typical of those in other peats, isotopic data identified marine organic matter as the main source of $\mathrm{N}$ and a minor source of $\mathrm{C}$ in the peat and showed that the unknown seabird was a fish-eating species that was summer-resident for the $2000 \mathrm{yr}$ period. Concentrations of $\mathrm{Cd}, \mathrm{Br}, \mathrm{Sr}$, and $\mathrm{Zn}$ in peat were up to an order of magnitude higher than in ombrotrophic (air-fed) bogs elsewhere, whereas $\mathrm{Hg}$ and $\mathrm{Cu}$ concentrations were similar to those in other peats, suggesting relatively low levels of $\mathrm{Hg}$ and $\mathrm{Cu}$ in the guano. This surprising result for $\mathrm{Hg}$ contrasts with studies on modern seabirds, in which guano markedly increased environmental $\mathrm{Hg}$ concentrations. It could be a consequence of $\mathrm{Hg}$ concentrations in Arctic marine food webs in the pre-industrial period that were an order of magnitude lower than those of today.
\end{abstract}

Key words: mercury; cadmium; seabirds; guano; peat; North Water polynya; Holocene; Thermal Maximum

RÉSUMÉ. On sait aujourd'hui que le guano d'oiseaux marins provenant des grandes colonies nicheuses fait augmenter les teneurs en métaux-traces dans les milieux terrestres adjacents et que tous les océans sont contaminés au $\mathrm{Hg}$, au Cd et autres métaux. Toutefois, l'effet du guano d'oiseaux marins dans la période préindustrielle a rarement fait l'objet d'études. Nous avons utilisé des isotopes stables de carbone d'azote et des analyses d'oligoéléments d'une carotte de tourbe, qui représente environ 2000 ans d'accumulation de matières organiques, pour examiner l'effet de la présence d'une colonie d'oiseaux marins qui a existé dans le nord de la baie de Baffin pendant le maximum thermique de l'Holocène (environ 8000 à 5000 ans BP) sur les oligoéléments et les nutriments. Même si les concentrations de $\mathrm{C}$ et de $\mathrm{N}$ étaient semblables à celles se trouvant dans d'autres tourbes, les données isotopiques ont démontré que la principale source de $\mathrm{N}$, et une source mineure de $\mathrm{C}$, provenaient de matières organiques marines, indiquant ainsi que les oiseaux marins inconnus étaient des espèces piscivores qui y ont résidé l'été pendant 2000 ans. Les concentrations de $\mathrm{Cd}, \mathrm{Br}, \mathrm{Sr}$ et $\mathrm{Zn}$ dans la tourbe étaient d'un ordre de grandeur supérieur à celles des tourbières ombrotrophes (alimentées par l'air) d'ailleurs, tandis que les concentrations de $\mathrm{Hg}$ et de $\mathrm{Cu}$ étaient semblables à celles d'autres tourbes, ce qui laisse sous-entendre des niveaux relativement bas de $\mathrm{Hg}$ et $\mathrm{Cu}$ dans le guano. Ce résultat concernant le Hg est surprenant, car il est contraire aux études modernes sur les oiseaux marins démontrant que le guano a considérablement augmenté les concentrations de $\mathrm{Hg}$ dans l'environnement. Cette augmentation pourrait être attribuable aux concentrations de $\mathrm{Hg}$ dans les réseaux alimentaires marins de l'Arctique lors de la période préindustrielle, d'un ordre de grandeur inférieur aux concentrations d'aujourd'hui.

Mots clés : mercure; cadmium; oiseaux marins; guano; tourbe; polynie des eaux du Nord; Holocène; maximum thermique

Traduit pour la revue Arctic par Nicole Giguère.

\section{INTRODUCTION}

Understanding the processes controlling the distribution of potentially toxic trace metals such as mercury $(\mathrm{Hg})$ and cadmium $(\mathrm{Cd})$ in the Arctic is an important step in evaluating the risk they pose to humans and wildlife. Currently, these metals occur in sufficiently high concentrations in some areas and in some animal species to pose a potential

\footnotetext{
${ }^{1}$ Corresponding author: Centre for Earth Observation Science, University of Manitoba, 125 Dysart Road, Winnipeg, Manitoba

R3T 2N2, Canada; Geological Survey of Canada, Natural Resources Canada, 601 Booth Street, Ottawa, Ontario K1A 0E8, Canada; peter.outridge@canada.ca

${ }^{2}$ Institute of Technology and Innovation, University of Southern Denmark, Campusvej 55, 5230 Odense M, Denmark

${ }^{3}$ Geological Survey of Denmark and Greenland (GEUS), Øster Voldgade 10, DK-1350 Copenhagen K, Denmark

${ }^{4}$ European Commission Joint Research Centre, Institute for Transuranium Elements, 76125 Karlsruhe, Germany

${ }^{5}$ Department of Renewable Resources, University of Alberta, Edmonton, Alberta T6G 2H1, Canada

(C) The Arctic Institute of North America
} 
risk to wildlife or to human consumers of wild animals (AMAP, 2005, 2011).

The role that biological vectors such as seabirds and anadromous fishes play in metal cycling in the Arctic environment has received increased attention recently, following the seminal work on the subject by Blais et al. (2005). It has been known for some time that the substantial quantities of marine-derived organic matter and nutrients deposited on shore in the guano of large populations of nesting seabirds can greatly increase productivity in receiving polar ecosystems (Cocks et al., 1998; Wainwright et al., 1998). The guano is also rich in certain metals and organic contaminants acquired from marine food chains, and studies have shown that the runoff from colonies significantly elevates the levels of a number of metals (Godzik, 1991; Brimble et al., 2009a; Choy et al., 2010) and organic contaminants (Blais et al., 2005; Foster et al., 2011) in nearby terrestrial and freshwater areas.

Most published studies on seabirds as biovectors have concerned environments of modern times, when industrial pollution has increased the concentrations of $\mathrm{Hg}$ and $\mathrm{Cd}$ in the world's oceans (Sunderland and Mason, 2007; Cullen and Maldonado, 2013). For Hg, these increases in seawater have been mirrored in food chains. For example, a synthesis by Dietz et al. (2009) showed that current levels of $\mathrm{Hg}$ in a variety of Arctic marine mammal and seabird populations are consistently ca. 10 times those of the pre-1850 period. There is no evidence, however, that $\mathrm{Cd}$ or other trace metals are generally elevated in modern Arctic animals (Outridge et al., 1997, 2005; AMAP, 2005). Given these historical changes, or the lack thereof, would seabird biovectors in the pre-industrial period have had significant effects on concentrations of metals and nutrients in terrestrial and freshwater environments, as they do in modern times? Also, because the abundance of different polar seabird populations is strongly but variably influenced by climatic shifts (Stempniewicz et al., 2007), did the delivery of nutrients and metals from seabird biovectors vary as climate changed during the Holocene? These questions have rarely been investigated. Nie et al. (2012) reported that variations in the deposition of penguin and seal feces into an Antarctic pond, caused by climate-related population fluctuations, have had significant effects on background sedimentary $\mathrm{Hg}$ concentrations and fluxes over the past seven centuries.

The goal of this paper is to explore these questions in an Arctic setting. We studied a mid-Holocene peat profile that is known to have been associated with a colony of seabirds on the Carey Islands, northern Baffin Bay, for more than 2000 years (Bennike et al., 2008) to assess the impact of the birds on $\mathrm{Hg}, \mathrm{Cd}$, and other elements, including nutrients nitrogen $(\mathrm{N})$ and carbon $(\mathrm{C})$. Stable isotopes of $\mathrm{C}$ and $\mathrm{N}$ were used to reconstruct variations in seabird guano inputs, because these isotopes have proven to be informative about organic matter and nutrient sources. Stable $\mathrm{N}$ isotope ratios (represented as $\delta^{15} \mathrm{~N}$ ) in animal tissues increase by approximately $2 \% 0-4 \%$ with each trophic level, providing a means to infer the trophic level at which the birds were feeding (Peterson and Fry, 1987; Hobson et al., 2002). $\delta^{13} \mathrm{C}$ values often exhibit lower trophic fractionation $(0.8 \% 0-1.0 \%$ o per level), but may be indicative of the sources of carbon within a food web. Other elements examined included bromine $(\mathrm{Br})$ and strontium $(\mathrm{Sr})$, two additional possible indicators of marine inputs, as well as copper $(\mathrm{Cu})$ and zinc $(\mathrm{Zn})$, which are biologically essential metals and exhibit the highest concentrations of any metal in seabird tissues in the North Water (NOW) polynya of Baffin Bay (Campbell et al., 2005). Marked climate shifts are known to have occurred in this region during the mid-Holocene (Vinther et al., 2009), so we examine possible relationships between reconstructed temperature histories, seabird-derived organic matter, and metal concentrations.

\section{MATERIALS AND METHODS}

\section{Environmental Setting and Peat Growth History}

The study site $\left(76^{\circ} 44.3^{\prime} \mathrm{N}, 73^{\circ} 12.5^{\prime} \mathrm{W}\right)$ is located on Nordvestø, the largest island in the Carey Islands group $60 \mathrm{~km}$ off northwest Greenland (Fig. 1). The island (ca. $16 \mathrm{~km}^{2}$ ) consists mostly of a rolling elevated plateau (140-230 m a.s.l.) above steep gneissic cliffs. The Carey Islands lie within the NOW polynya, one of the largest Arctic polynyas, which supports a highly productive marine ecosystem in northern Baffin Bay (Tremblay et al., 2006). The present climate is High Arctic, with mean monthly temperatures at the Thule Air Base $115 \mathrm{~km}$ east of the Carey Islands ranging from $-24.6^{\circ} \mathrm{C}$ in February to $4.5^{\circ} \mathrm{C}$ in July, and an annual average of $-11.2^{\circ} \mathrm{C}$ (ClimaTemps, 2015). Vegetation consists of a thin cover of bryophytes, dwarf shrubs, and perennial herbs and is classified as High Arctic tundra.

A series of peat moss hummocks up to $2.5 \mathrm{~m}$ high and up to $\sim 8 \mathrm{~m}$ in diameter (M. Goodsite, pers. observ.) are found on rocky ground at an elevation of $140 \mathrm{~m}$ above sea level, close to the northern rim of the island below a north-sloping ridge (see photographs in Brassard and Blake, 1978). The mostly frozen hummocks consist of well-preserved remains of the coprophilous moss Aplodon wormskioldii, with an active layer $\sim 10 \mathrm{~cm}$ deep in July (M. Goodsite, pers. observ.). This species is exclusively associated with dung, guano, or other N-enriched substrates (Steere, 1973). Radiocarbon dating of one hummock by Brassard and Blake (1978) gave a basal peat date of $6300 \mathrm{yr}$ BP (conventional ${ }^{14} \mathrm{C}$ years) at $253-258 \mathrm{~cm}$ depth, while another age at the top of the hummock indicated that peat growth ceased at some point between 4500 and $4000 \mathrm{yr}$ BP. Later, more extensive dating of another hummock nearby gave median ages of 7110 to $5135 \mathrm{cal}$. yr BP from $205 \mathrm{~cm}$ to the top of the frozen peat (Bennike et al.; 2008; see online Appendix 1: Fig. S1). Both sets of results place the period of peat growth during the mid-Holocene Thermal Maximum, which is thought to have occurred between 8000 and $5000 \mathrm{yr}$ BP in the eastern Canadian Arctic and North Greenland (Gajewski, 2015). 

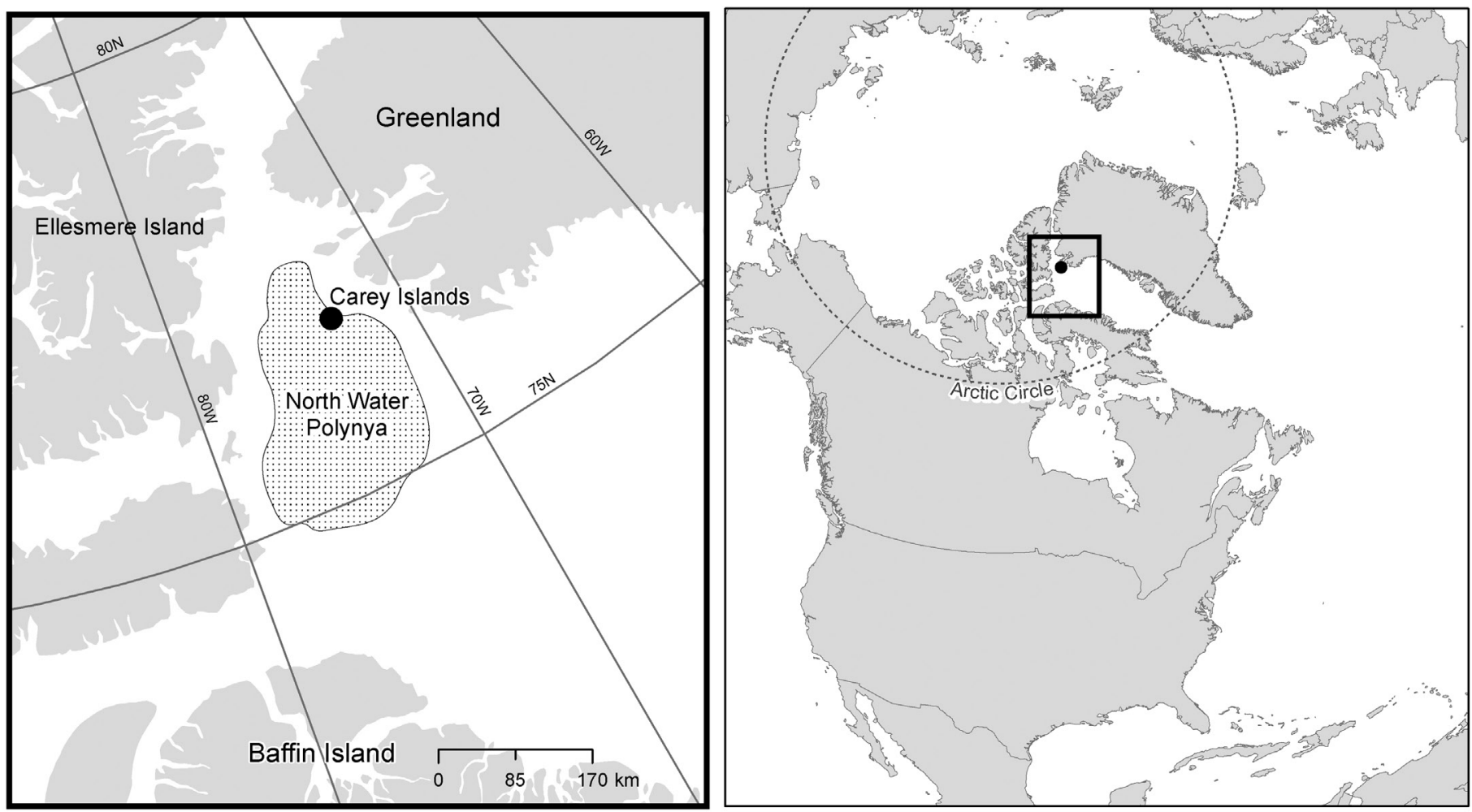

FIG. 1. Map showing location of the Carey Islands study site, with the approximate summer position of the North Water Polynya indicated by cross-hatching

After this warm period, plant growth was negligible until recent decades owing to a colder climate and snow accumulation over the hummocks, which lasted into summer (Brassard and Blake, 1978).

The $A$. wormskioldii peat hummocks are associated with a former large nesting colony of seabirds, as indicated by fragments of feathers throughout the peat profiles, although no seabirds currently nest on this site (Brassard and Blake, 1978; Bennike et al., 2008). We attempted to identify the bird species from feather remains or by extracting bird DNA from the peat, but without success. The question of which species was involved is discussed later.

\section{Field Work and Sample Preparation}

The peat core described by Bennike et al. (2008) was used for the present study. Briefly, one of the larger peat hummocks at the site was cored to a depth of $207 \mathrm{~cm}$ in July 2001. A motorized peat corer (Nørnberg et al., 2004) was used because all but the upper few centimetres of peat is permanently frozen. The thawed active layer was discarded before coring, so that the samples represent only frozen peat. The core diameter was $9.7 \mathrm{~cm}$, and core recovery was $100 \%$. The core sections were frozen and returned to Denmark, where they were sectioned into $1 \mathrm{~cm}$ increments while in a frozen state. Part of each slice was set aside for biological analyses and part for chemical analysis. The latter samples were freeze-dried, and obvious fragments of feathers were removed. The edges of the peat slices were trimmed away with an acid-rinsed ceramic knife, and the remaining sample was homogenized in a centrifugal mill equipped with a titanium rotor and $0.25 \mathrm{~mm}$ Ti sieve (Ultracentrifugal Mill ZM 1-T, F. K. Retsch GmbH and Co., Haan, Germany).

\section{Analytical Procedures and Statistics}

Powdered subsamples of dried peat ( $100 \mathrm{mg})$ were analyzed for total $\mathrm{Hg}$ by solid sample thermal desorption analyzer (LECO AMA-254), calibrated with Hg solutions of known concentrations prepared daily. Standard reference materials (SRMs) included with the analyses (BCR-281 Rye Grass $[N=7]$ and NIST 1515 Apple Leaves $[N=3])$ gave measured mean \pm SD values of $19.5 \pm 1.5$ and $43.3 \pm$ $0.9 \mathrm{ng} / \mathrm{g}$ DW compared with certified values of $21 \pm 2$ and $44 \pm 4 \mathrm{ng} / \mathrm{g}$ DW, respectively. The calculated lower limit of detection of the method was $4.4 \mathrm{ng} / \mathrm{g}$ DW.

Cadmium was determined by acid digestion $\left(\mathrm{HF} / \mathrm{HNO}_{3}\right)$ of $\sim 100 \mathrm{mg}$ samples followed by graphite furnace absorption spectrometry (GF-AAS) on digest solutions diluted as appropriate to remain within the working range. A subset of the digest solutions was reanalyzed with flame AAS (which has a higher working range) because of the high concentrations. The median difference between methods was 5.8\% (GF-AAS data were higher on average). Concurrent analysis of SRM BCR-62 Olive Leaves $(N=6)$ gave a mean \pm SD concentration of $0.095 \pm 0.020 \mu \mathrm{g} / \mathrm{g} \mathrm{DW}$, which compared well with the certified value of $0.10 \pm 0.02 \mu \mathrm{g} / \mathrm{g}$ DW. Repeated analysis of two samples throughout the analytical work gave procedural relative standard deviations of $13.4 \%$ 
and $12.8 \%(N=20$ each). The lower limit of detection was $0.03 \mu \mathrm{g} / \mathrm{g}$ DW.

The other trace elements $(\mathrm{Br}, \mathrm{Sr}, \mathrm{Cu}$, and $\mathrm{Zn})$ were determined in powdered subsamples by $\mathrm{x}$-ray fluorescence (Energy-dispersive Miniprobe Multielement Analyzer [EMMA]) as described by Cherbukin and Shotyk (1996). The instrument was calibrated with a variety of international plant and soil SRMs, and the analytical accuracy and precision values were reported by Shotyk et al. (2000). The lower limits of detection (in $\mu \mathrm{g} / \mathrm{g}$ DW) of the elements reported here are $0.5 \mathrm{Br}, 1.0 \mathrm{Sr}, 2.0 \mathrm{Cu}$, and $1.4 \mathrm{Zn}$.

This study employed stable isotope ratios of $\mathrm{C}$ and $\mathrm{N}$, as well as total organic carbon (TOC) and total nitrogen (TN) concentrations, to better understand and quantify the impact of seabird guano on metal profiles, as recommended by Hobson (2005). Stable C and N isotopes, TOC, and $\mathrm{TN}$ were determined through combustion conversion of sample material to $\mathrm{N}_{2}$ and $\mathrm{CO}_{2}$ gases, which were carried in helium through a Costech Instruments Elemental Analyzer (CHNS-O ECS 4010, Milan) coupled to a Deltaplus XL Continuous Flow Stable Isotope Ratio Mass Spectrometer (Thermo Finnigan, Bremen). Samples were pre-rinsed with dilute hydrochloric acid to remove carbonates. We weighed a $0.5 \mathrm{mg}$ subsample for TOC and ${ }^{13} \mathrm{C} /{ }^{12} \mathrm{C}$ determinations and a $1.5-2 \mathrm{mg}$ subsample for TN and ${ }^{15} \mathrm{~N} /{ }^{14} \mathrm{~N}$ determinations. Sample and standard gases for N measurements were first passed through a Carbopure trap to remove $\mathrm{CO}_{2}$. Carbon isotope ratio data are expressed in standard notation $\left(\delta^{13} \mathrm{C}\right)$ relative to Vienna PeeDee Belemnite, and $\mathrm{N}$ isotope ratios, as $\delta^{15} \mathrm{~N}$ relative to $\mathrm{N}_{2}$ in air. Data quality was monitored and corrections made using an array of international reference material and in-house standards that are calibrated using certified SRMs: IAEA-N1 + IAEA-N2 (Ammonium Sulphate), IAEA-CH3 (cellulose) + IAEACH6 (sugar), USGS-40 + USGS-41 (L-Glutamic Acid). These SRM measurements were used in data normalization and to ensure daily mass spectrometry precision and accuracy. With these quality control checks, the expected accuracies for reportable data are $+0.2 \%$ for $\delta^{13} \mathrm{C}$ and $+0.3 \%$ for $\delta^{15} \mathrm{~N}$. Duplicate measurements were made at the end of the sample batch on three samples interspersed throughout the run, giving mean differences between duplicates of $0.52 \%$ DW for TOC, $0.04 \%$ for TN, $0.15 \%$ for $\delta^{13} \mathrm{C}$, and $0.09 \%$ for $\delta^{15} \mathrm{~N}$.

Data on several animal macrofossils (number of bird feathers, chironomid midge head capsules, and Cyclorrapha fly head capsules) reported by Bennike et al. (2008) are included in the present paper because their abundances were found to be significantly correlated with one or more chemical variables. Briefly, the frozen section of each slice set aside for biological analysis was thawed and wet-sieved on 0.4 and $0.2 \mathrm{~mm}$ sieves, and the residues were examined microscopically.

Relationships between elements, stable isotope ratios, and biological variables were initially tested statistically using non-parametric Spearman Rank Order correlation, whereas differences in metal concentrations between time periods were tested with Kruskal-Wallis One-Way ANOVA on Ranks (SigmaPlot v. 12.5, Systat ${ }^{\circledR}$ Software). These tests are not affected by deviations from data normality and homoscedasticity. Subsequently, the relative importance of organic matter concentration (TOC and TN) and source indicators $\left(\delta^{15} \mathrm{~N}\right.$ and $\left.\delta^{13} \mathrm{C}\right)$ in explaining metal concentration variability were tested with forward stepwise linear regression modeling (SigmaPlot v. 12.5). Concentration and isotope ratio data were $\log _{\mathrm{n}}$ transformed prior to analysis (Sokal and Rohlf, 1981), which resulted in normally distributed data in all cases. Significant relationships noted in the text are at $p<0.05$ unless otherwise stated.

\section{RESULTS AND DISCUSSION}

\section{Carbon and Nitrogen as Seabird Input Indicators}

Total organic carbon concentrations and $\delta^{13} \mathrm{C}$ in bulk peat were not correlated (Table 1). Concentrations of TOC (mean + SD: $45.4+0.8 \%$ dry wt; Fig. 2 a) were similar to values in pre-industrial ombrotrophic (precipitation- and air-fed) peats that were remote from marine influence (Disnar et al., 2008; Outridge and Sanei, 2010; Esmeijer-Liu et al., 2012). However, $\delta^{13} \mathrm{C}$ values in $A$. wormskioldii suggested that marine inputs of $\mathrm{C}$ were a minor yet significant fraction of total $\mathrm{C}$ throughout the $2000 \mathrm{yr}$ study period, mixed with terrestrial (soil/atmospheric) C. Stable C isotopic ratios in the peat reflect the uptake of $\mathrm{C}$ derived from two possible sources: marine organic matter $(\mathrm{OM})$ and terrestrial C. These sources, or "isotopic end-members," currently exhibit distinctly different ranges of isotope ratios (see below). By comparing peat isotopic values with endmember values, we can infer the relative importance of the different sources by proportion (Hobson et al., 1994; Robinson, 2001). However, the $\delta^{13} \mathrm{C}$ end-member values must be corrected for the effects of anthropogenic $\mathrm{CO}_{2}$ emissions that exhibit depleted ${ }^{13} \mathrm{C}$ and have lowered average marine and terrestrial $\mathrm{OM} \delta^{13} \mathrm{C}$ since the beginning of the Industrial Revolution (the "Suess Effect"; Keeling, 1979). These adjustments should be regarded as approximate, particularly for terrestrial plant OM, because other variables that may change over long periods of time, such as air temperature, precipitation, and soil moisture, can also significantly affect plant $\delta^{13} \mathrm{C}$ values (Tillman et al., 2010). Regional variations in the impact of the Suess Effect in oceans can also be expected (Bauch et al., 2000).

In the NOW polynya at present (samples taken in the $1990 \mathrm{~s}), \delta^{13} \mathrm{C}$ in marine $\mathrm{OM}$ ranged from $-22.5 \%$ to $-18 \%$ o (Hobson et al., 2002; Campbell et al., 2005), which is markedly higher than the range of $-32.1 \%$ to $-25.8 \%$ in terrestrial plants of the Carey Islands region (Blake, 1991). Average $\delta^{13} \mathrm{C}$ of $-27 \%$ in terrestrial OM in the Arctic Ocean (Schubert and Calvert, 2001) is consistent with the Carey Islands terrestrial values. This $\delta^{13} \mathrm{C}$ value is typical of modern terrestrial $\mathrm{C}_{3}$ plants in general, including mosses, which ranged from $-35 \%$ to $-22 \%$ with a mean of $-27 \%$ (Meyers, 
TABLE 1. Results of non-parametric Spearman Rank correlation analyses of elemental, isotopic, and biological variables in the peat core over two millennia. ("C. hir" - chironomid (midge) abundance; "C. ych" - Cyclorropha sp. (fly) abundance; "Feathers" - abundance of bird feathers. Values shown are correlation " $r$ " coefficients; significance levels indicated as: * $-p<0.05, * *-p<0.01, * *$ with bold font $-p<0.001$. N varied between pair comparisons: $\mathrm{N}=189-205$ for inter-element pairs, $\mathrm{N}=37$ for element-isotope and element-TOC and -TN pairs, $\mathrm{N}=97-103$ for element-biological pairs, and $\mathrm{N}=37$ for isotopic-, TOC-, and TN-biological pairs).

\begin{tabular}{|c|c|c|c|c|c|c|c|c|c|c|c|c|}
\hline $\mathrm{Hg}$ & $0.465^{* *}$ & -0.097 & $0.141^{*}$ & $0.659 * *$ & $0.647 * *$ & 0.085 & $0.550 * *$ & 0.083 & 0.237 & $0.416 * *$ & $0.353 * *$ & 0.080 \\
\hline $\mathrm{Cd}$ & & $-0.200^{* *}$ & $0.240 * *$ & $0.571 * *$ & 0.560 ** & -0.024 & $0.492 * *$ & 0.003 & $0.418^{*}$ & $0.309 * *$ & 0.173 & $0.205^{*}$ \\
\hline $\mathrm{Zn}$ & & & & $0.295 * *$ & $0.198 * *$ & -0.153 & $0.598 * *$ & -0.325 & $0.497 * *$ & -0.117 & -0.080 & 0.153 \\
\hline $\mathrm{Br}$ & & & & & 0.736 ** & -0.102 & $0.712 * *$ & -0.155 & $0.443 * *$ & $0.306^{* *}$ & 0.181 & -0.004 \\
\hline $\mathrm{Sr}$ & & & & & & -0.170 & $0.652 * *$ & 0.076 & $0.429 * *$ & $0.413^{* *}$ & $0.278^{* *}$ & 0.141 \\
\hline TOC & & & & & & & 0.0868 & -0.010 & $-0.335^{*}$ & 0.296 & 0.168 & -0.174 \\
\hline$\delta^{15} \mathrm{~N}$ & & & & & & & & & & 0.052 & 0.068 & 0.196 \\
\hline C. hir & & & & & & & & & & & $0.535 * *$ & -0.078 \\
\hline C. ych & & & & & & & & & & & & -0.076 \\
\hline
\end{tabular}
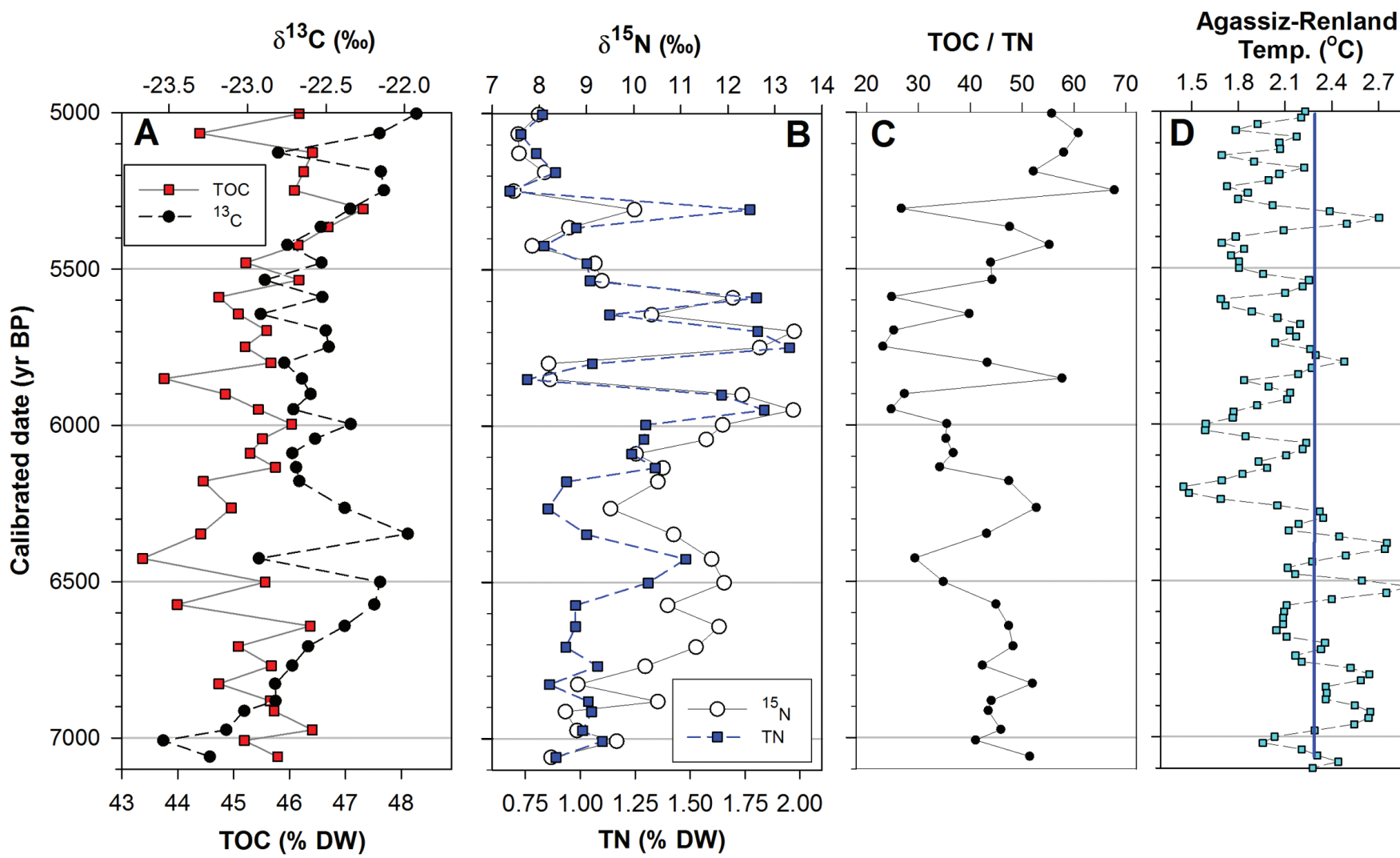
Temp. $\left({ }^{\circ} \mathrm{C}\right)$

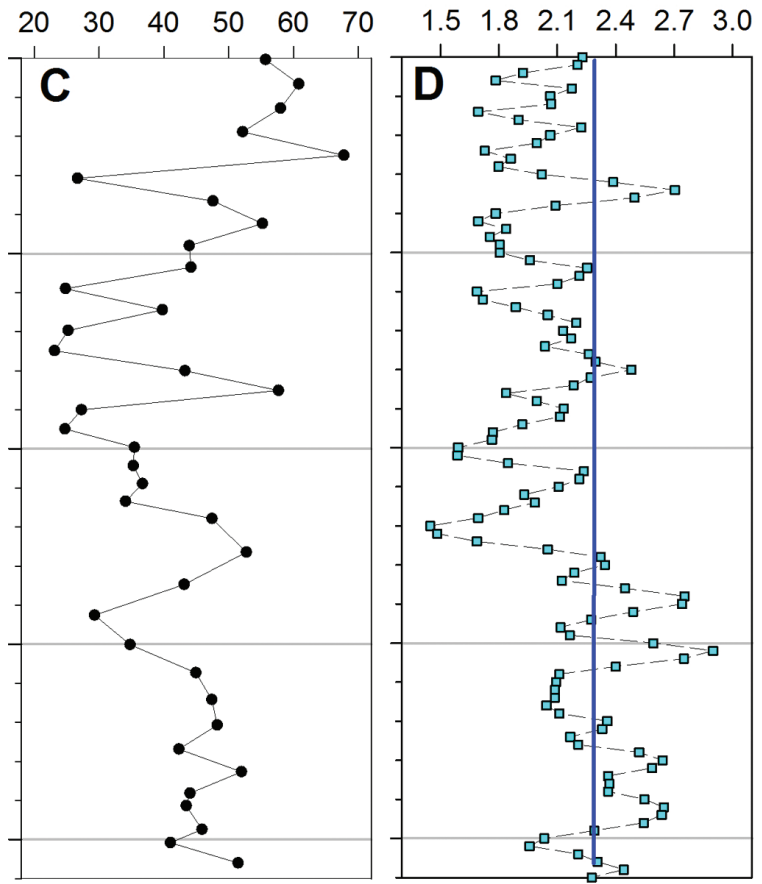

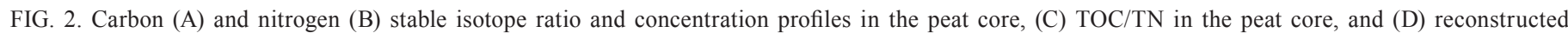

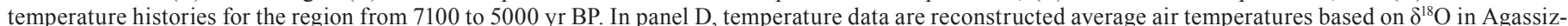

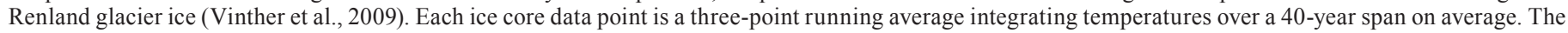
vertical line in (D) is the mean temperature for the period 10200 to $5000 \mathrm{yr}$ BP.

1994; Koch, 1998). Terrestrial plant $\delta^{13} \mathrm{C}$ has exhibited an average decline of $\sim 2.7 \%$ since the industrial era began (Zhao et al., 2001), while Arctic marine food chains may have experienced a decrease of $2 \%$ (Bauch et al., 2000, 2002). Thus, if the modern terrestrial and marine $\delta^{13} \mathrm{C}$ endmembers are assumed to be $-27 \%$ and $-20 \%$, respectively, the Suess Effect-corrected Holocene end-member values would be $-24.3 \%$ and $-18 \%$. All of the peat samples (mean $-22.6 \pm 0.3 \%$, range -23.5 to $-21.9 \%$; Fig. 2a) fell between the terrestrial and marine $\delta^{13} \mathrm{C}$ end-members, which indicates a mixture of sources. A 50:50 mix of terrestrial and marine $\mathrm{C}$ in peat should exhibit $\delta^{13} \mathrm{C}$ of $-21.2 \%$; the mean peat $\delta^{13} \mathrm{C}$ of $-22.6 \%$ suggests an average $73: 27$ ratio of terrestrial to marine sources. 
Total $\mathrm{N}$ in $A$. wormskioldii averaged $1.1 \pm 0.3 \% \mathrm{DW}$, which is comparable to that in pre-industrial ombrotrophic peats elsewhere (Esmeijer-Liu et al., 2012). However, $\delta^{15} \mathrm{~N}$ results suggested that the marine source (guano) made more difference to the total amount of $\mathrm{N}$ in peat than to the total amount of C. Unlike $\delta^{13} \mathrm{C}$ end-members, $\delta^{15} \mathrm{~N}$ endmember values were not adjusted for anthropogenic $\mathrm{N}$ effects in the 20th century because of a lack of evidence for significant changes in baseline $\delta^{15} \mathrm{~N}$ in Arctic marine foodchains since the pre-industrial period (Outridge et al., 2005, 2009) and conflicting evidence for a shift in northern terrestrial plants. Although Esmeijer-Liu et al. (2012) reported a substantial decrease in peat $\delta^{15} \mathrm{~N}$ over the past few centuries, they attributed this change partly to diagenesis of the older OM. Values of $\delta^{15} \mathrm{~N}$ in the teeth and bones of a range of northern terrestrial herbivore species from the Pleistocene and Holocene were similar to those of their modern counterparts (Bocherens et al., 1997, 2015), suggesting that the $\delta^{15} \mathrm{~N}$ values of their forage plants were also similar. In the absence of a clearly substantiated correction factor, the modern $\delta^{15} \mathrm{~N}$ end-member values are applied here to the mid-Holocene peat data.

$\delta^{15} \mathrm{~N}$ in Arctic terrestrial plant $\mathrm{OM}$ unaffected by marine $\mathrm{N}$ ranges from ca. $-5 \%$ to $+2 \%$ (Schubert and Calvert, 2001; Kristensen et al., 2011), which is clearly well below the values in $A$. wormskioldii (range: $7.5 \%$ o to $13.2 \%$, mean \pm SD: $10.0 \%{ }_{0} \pm 1.7 \%$; Fig. $\left.2 b\right)$. The peat $\delta^{15} \mathrm{~N}$ data are thus indicative of predominantly marine $\mathrm{N}$ inputs. However, the selection of a marine end-member value to exactly quantify the marine input is problematic. Since the identity of the mid-Holocene seabird species is not known with certainty, its likely trophic position and guano $\delta^{15} \mathrm{~N}$ value cannot be ascertained directly. In the NOW ecosystem, $\delta^{15} \mathrm{~N}$ values exhibit a range of 5\% to 7\% in marine particulate and algal $\mathrm{OM}$ and increase by $3.8 \%$ on average at each trophic level above this baseline (Hobson et al., 2002; Campell et al., 2005), which is typical of $\delta^{15} \mathrm{~N}$ patterns in food-chains. Seabirds currently inhabiting the NOW polynya exhibit average muscle $\delta^{15} \mathrm{~N}$ values ranging from $10.9 \%$ in the zooplantivorous Dovekie (Alle alle) to $16.5 \%$ - $17.2 \%$ in two species of piscivorous gulls (L. hyperboreus and L. thayeri), and these values reflect their different trophic niches (Campbell et al., 2005).

A possible trophic position for the seabird can be calculated from the peat $\delta^{15} \mathrm{~N}$ data. Total $\mathrm{N}$ concentrations and $\delta^{15} \mathrm{~N}$ in peat had a high positive correlation $(p<0.001$, Table 1), which indicates that peat $\delta^{15} \mathrm{~N}$ was tightly controlled by the amount of TN inputs from guano. Coincident peaks of high $\mathrm{TN}$, and high $\delta^{15} \mathrm{~N}$ values up to $13.2 \%$, occurred several times between 6000 and $5500 \mathrm{yr}$ BP. Peat $\delta^{15} \mathrm{~N}$ represents a mixture of marine and terrestrial sources ranging from $0 \%$ to $100 \%$. Since marine $\mathrm{N}$ cannot have contributed more than $100 \%$ of peat $\mathrm{TN}$, the maximum peat $\delta^{15} \mathrm{~N}$ value of $13.2 \%$ means that the average guano $\delta^{15} \mathrm{~N}$ value must have been $13.2 \%$ or greater. In addition, some degree of isotopic fractionation can be expected between the guano and seabird tissues because of $\mathrm{N}$ metabolism.
Wainwright et al. (1998) reported that guano in several Arctic seabird species was depleted in ${ }^{15} \mathrm{~N}$ relative to blood (representing their tissues): guano $\delta^{15} \mathrm{~N}$ was on average $2.5 \%$ below blood values. If this average can be applied to the peat (guano) values in this study as a correction factor, then the unknown seabird species may have had an average tissue $\delta^{15} \mathrm{~N}$ value of at least $15.7 \%$ o (minimum guano $\delta^{15} \mathrm{~N}$ of $13.2 \%$ o $+2.5 \%$ fractionation correction). On the basis of the NOW basal food web $\delta^{15} \mathrm{~N}$ values of $5 \%$ - 7\%o (average of $6 \%$ ) and an increase of 3.8\% at each trophic level (Hobson et al., 2002), it may be inferred that the mid-Holocene seabirds were feeding at least 2.6 trophic levels $((15.7-6) / 3.8$ $=2.6$ ) above the marine algal baseline, on prey items such as zooplanktivorous and piscivorous fish species (cf. Bradstreet and Brown, 1985; Campbell et al., 2005). This inference should be treated cautiously, because the guano $\delta^{15} \mathrm{~N}$ values may have been altered after deposition by ammonification of urea-N, which has the potential to significantly increase the $\delta^{15} \mathrm{~N}$ signature of TN (Mizutani et al., 1986). Conversely, there may have been some contribution to peat $\mathrm{TN}$ from prey (fish) debris dropped near the colony, which would likely have had a lower average $\delta^{15} \mathrm{~N}$ value than guano, being a trophic level lower than the seabird tissues. This process would have tended to counteract the ammonification effect on peat $\delta^{15} \mathrm{~N}$.

The finding of a dominant marine source of $\mathrm{N}$, and lesser marine $\mathrm{C}$, in the peat is unlikely to be affected by $\mathrm{OM}$ decomposition and its effects on $\mathrm{C}$ and $\mathrm{N}$ isotopic ratios. $\mathrm{TOC} / \mathrm{TN}, \delta^{13} \mathrm{C}$ and $\delta^{15} \mathrm{~N}$ values in peat bogs may be altered by decomposition to produce characteristic patterns (Agren et al., 1996; Kuhry and Vitt, 1996; Zaccone et al., 2011). The magnitude of $\delta^{13} \mathrm{C}$ and $\delta^{15} \mathrm{~N}$ alteration due to long-term $\mathrm{OM}$ diagenesis in a variety of environments, including peat bogs, is less than $\sim 2 \%$ for both isotope systems (Meyers, 1994; Sharma et al., 2005; Zaccone et al., 2011). This effect is minor compared to the difference between the average terrestrial and marine $\delta^{15} \mathrm{~N}$ end-members in the Baffin Bay region. Decomposition also tends to produce smooth trends in TOC, TN, and isotope ratios downcore, unlike the rapid $4 \%{ }_{0}-5 \%$ fluctuations of $\delta^{15} \mathrm{~N}$ in $A$. wormskioldii. We conclude therefore that any decomposition effects on peat $\mathrm{OM}$ stable isotopic values were negligible and will not alter the findings of the study. This conclusion is consistent with Brassard and Blake's (1978) report of remarkably well-preserved cells and macroscopic structures of $A$. wormskioldii leaves.

To explore possible relationships between changing Holocene climate and seabird abundance, we investigated whether changes in peat $\delta^{15} \mathrm{~N}$ and TN concentrations may be semi-quantitative indicators of seabird abundance. Peat TN increased or decreased by up to two-fold from one data point to the next several times between 6000 and $5300 \mathrm{yr}$ BP; simultaneously, $\delta^{15} \mathrm{~N}$ fluctuated rapidly, by up to $5 \%$ within 100 years (Fig. 2b). If it is assumed that TN is proportional to guano deposition onto the peat surface and that the deposition value was related to seabird abundance at the time, then the isotopic evidence suggests that 
seabird abundance fluctuated dramatically in the latter part of the mid-Holocene Thermal Maximum. The suggested mechanism underlying a possible climate-bird abundance relationship is the link between air temperature and the summer ice-free area and productivity of the NOW polynya, where northern Baffin Bay seabirds feed during summer (Hobson et al., 2002). A warmer climate would favour a larger ice-free opening of the polynya, with the improved light climate supporting a more productive marine ecosystem (Hamel et al., 2002). In turn, this ecosystem could potentially support a larger population of nesting seabirds. The mid-Holocene Thermal Maximum was associated with relatively open summer waters in Baffin Bay, as evidenced by driftwood delivery to ancient beaches (Dyke et al., 1997) and diatom microfossils in marine sediments (Levac et al., 2001), which also suggest a larger and longer-lasting icefree polynya than currently. Organic indicators in marine sediment cores show that the productivity of marginal areas of the polynya, especially the northern margin near the Carey Islands, is particularly sensitive to climate-driven changes in sea-ice cover and nutrient supply, whereas the interior core area is relatively stable (Hamel et al., 2002; Bailey et al., 2013).

A reconstruction of air temperatures during the midHolocene based on two glacier ice cores from the region showed several points of coincidence between inferred peaks in air temperature and peat $\mathrm{TN}$ and $\delta^{15} \mathrm{~N}$, for example, at $5300 \mathrm{yr}$ BP and $6600-5900 \mathrm{yr}$ BP (Fig. 2d cf. 2b). But over the 2000-year study period as a whole, there were no significant correlations between air temperatures (interpolating ice core dates to match peat core dates) and the peat $\mathrm{C}$ and $\mathrm{N}$ isotopic and concentration profiles $(p>0.10$ in all cases). One possible explanation for the lack of an association is that the relationship between seabird abundance and summer air temperature, if there is one, is not linear. Although polynya area and productivity may be important factors in seabird abundance generally, other possible limiting factors, such as limited nesting areas, predators, or inter-specific competition, may be influential (Stempniewicz et al., 2007). The area of the NOW that is free of sea ice may also be affected by variations in Greenland glacier calving and wind and ocean circulation patterns that are not directly related to air temperature (Bailey et al., 2013).

Despite the absence of evidence for close control of seabird abundance by the relatively warm climate of the mid-Holocene Thermal Maximum, the isotopic evidence indicates that fish-eating seabirds nested at the study site during summer continuously throughout the 2000-year study period. The decline in peat TN and $\delta^{15} \mathrm{~N}$ after $5300 \mathrm{yr}$ BP could indicate a declining seabird population, a trend that accords well with climate reconstructions showing a transition to cooler temperatures commencing at $\sim 5200 \mathrm{yr}$ BP in North Greenland (Vinther et al., 2009; Gajewski, 2015). The continuous summer occupation when temperatures in North Greenland were on average $\sim 1^{\circ}-1.5^{\circ} \mathrm{C}$ higher than today (Gajewski, 2015), followed by population decline and colony abandonment after the mid-Holocene
Thermal Maximum until the present day, points to a primary relationship between climate and the presence or absence of the seabird species at the site. Although the date of complete abandonment of the nest site by the birds cannot be ascertained, it may have coincided with the cessation of peat growth soon after $\sim 5135 \mathrm{yr}$ BP (see online Fig. S1). With the recent warmer climate in northern Baffin Bay, summer populations of species such as the Atlantic Puffin (Fratercula arctica), which historically were locally rare, have been increasing, which could indicate that the species is recolonizing the area as summer temperatures increase (Burnham and Burnham, 2010).

\section{Seabirds as Metal Biovectors in the Mid-Holocene}

The patterns of isotopic ratios, as well as TOC and TN concentrations, may be compared to changes in peat metal concentrations (Fig. 3) to judge the impact of seabird guano on peat metal levels. A common feature of all of the metal profiles is significantly higher concentrations during the period from 6100 to $5500 \mathrm{yr}$ BP than before or after that period. Correlation analyses showed that $\mathrm{TN}$ and $\delta^{15} \mathrm{~N}$ were of greater importance in terms of peat element concentrations than TOC and $\delta^{13} \mathrm{C}$, which in most cases were not significantly influential variables (Table 1). Biological variables (invertebrate abundance in particular) were highly correlated with some elements, especially $\mathrm{Hg}$ and $\mathrm{Sr}$. Cadmium concentrations were correlated with chironomid abundance $(p<0.01)$ and number of bird feathers.

To judge the relative influence on metal levels of the changes in $\mathrm{C}$ and $\mathrm{N}$ isotopes and concentrations, each element was regressed against the $\mathrm{OM}$ variables using forward stepwise multiple linear regression. This analysis produced a ranked order of variables cumulatively explaining the most variance in metal concentrations (Table 2). Total N, which is assumed to represent variations in the amounts of deposited guano, was the most significant variable for all elements except $\mathrm{Cu}$, and the only one of significance for $\mathrm{Cd}, \mathrm{Br}$, and $\mathrm{Sr}$. Concentrations of peat $\mathrm{Hg}$ and $\mathrm{Cu}$ were also significantly $(p<0.001)$ affected by variations in $\delta^{15} \mathrm{~N}$. Mercury levels in different species in the NOW ecosystem today are highly correlated with trophic position as inferred from $\delta^{15} \mathrm{~N}$, and $\mathrm{Cu}$ is weakly correlated (Campbell et al., 2005). The peat results could be interpreted, therefore, to mean that variations in seabird trophic position during the mid-Holocene may have influenced the rates of $\mathrm{Hg}$ and $\mathrm{Cu}$ deposition onto the peat, separately from the effect of the guano deposition rate. However, the correlation between peat $\mathrm{TN}$ and $\delta^{15} \mathrm{~N}$ makes this conclusion problematic because the effect of isotopic variations may be confounded by changes in $\mathrm{N}$ input.

How do the metal concentrations in A. wormskioldii compare with those in other peat deposits from the preindustrial period? We have not found other literature reports of metals in guanogenic peat from this era. From the modern period, surface moss data from Spitsbergen showed that the ranges of $\mathrm{Cd}(1.1-8.0 \mu \mathrm{g} / \mathrm{g} \mathrm{DW}), \mathrm{Cu}(2.6-7.3 \mu \mathrm{g} / \mathrm{g}$ 

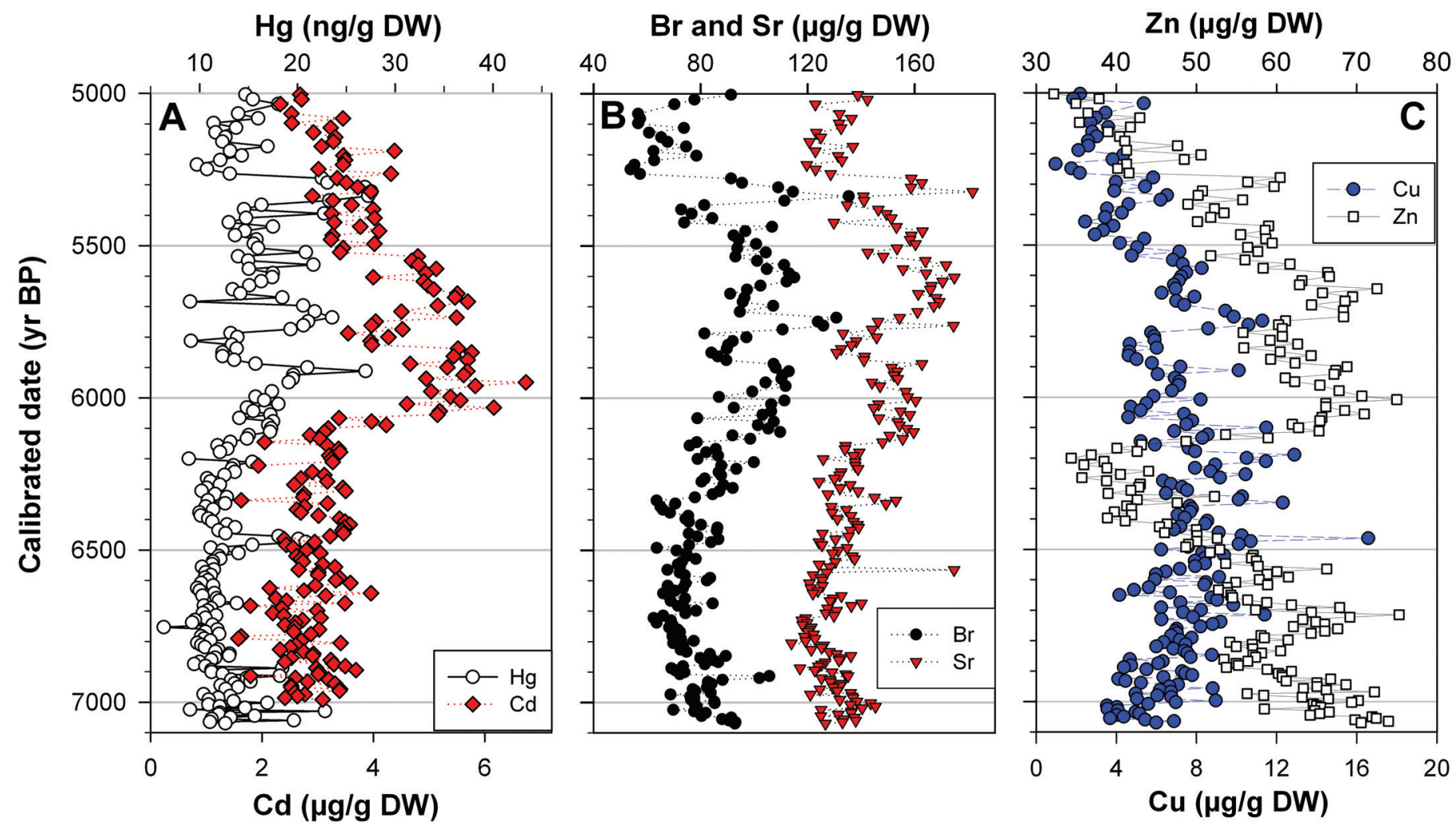

FIG. 3. Trace metal and other element concentrations in the Carey Islands peat core from 7100 to $5000 \mathrm{yr} \mathrm{BP}(\mathrm{A}) \mathrm{Hg}$ and $\mathrm{Cd}$, (B) $\mathrm{Br}$ and $\mathrm{Sr}$, and (C) $\mathrm{Cu}$ and $\mathrm{Zn}$.

TABLE 2. The significant organic matter concentration and source indicators that explain the most variance in peat trace element concentrations. Results of forward stepwise linear regressions are shown. Degrees of freedom $=36$ in all cases. Only the variables that contributed significantly to explaining element concentrations were included in the table.

\begin{tabular}{lcccr}
\hline \hline Element & Model step & Variable entered into model & Cumulative model $\mathrm{r}^{2}$ & Probability of entry into model \\
\hline $\mathrm{Hg}$ & 1 & $\mathrm{TN}$ & 0.45 & $<0.001$ \\
& 2 & $\delta^{15}$ & 0.64 & $<0.001$ \\
$\mathrm{Cd}$ & 1 & $\mathrm{TN}$ & 0.24 & 0.003 \\
$\mathrm{Br}$ & $\mathrm{TN}$ & 0.56 & $<0.001$ \\
$\mathrm{Sr}$ & $\mathrm{TN}$ & 0.43 & $<0.001$ \\
$\mathrm{Cu}$ & 1 & $\delta^{15}$ & 0.49 & $<0.001$ \\
& 1 & $\mathrm{TOC}$ & 0.55 & 0.027 \\
$\mathrm{Zn}$ & 2 & $\delta^{13} \mathrm{C}$ & 0.60 & 0.054 \\
& 3 & $\mathrm{TN}$ & 0.30 & $<0.001$ \\
\hline \hline
\end{tabular}

DW), and Zn (11-47 $\mu \mathrm{g} / \mathrm{g}$ DW) concentrations in two moss species (Sanionia uncinata and Hylocomium splendens) within a Dovekie colony were up to twice as high as in specimens collected outside the colonies (Godzik, 1991), and were similar to those in the mid-Holocene $A$. wormskioldii deposit (cf. Table 3). Ombrotrophic peat bogs from the Holocene may provide the closest point of comparison to the present study. The underlying rock substrate and absence of a water table mean that the $A$. wormskioldii hummocks were not minerogenic peat. Comparison of average element concentrations in the Carey Islands peat with those in preindustrial ombrotrophic peats elsewhere in the Northern Hemisphere shows that $\mathrm{Cd}, \mathrm{Br}, \mathrm{Sr}$, and $\mathrm{Zn}$ are substantially higher in A. wormskioldii (Table 3). The impact of guano on Cd concentrations ( $\sim 2-6 \mu \mathrm{g} / \mathrm{g}$ DW) was especially marked, and these concentrations fall in the lower half of the range of highly contaminated soils in a modern context (UNEP, 2010). For example, the Cd levels in A. wormskioldii are comparable to those in peats $25-43 \mathrm{~km}$ from the RouynNoranda $\mathrm{Cu}$ smelter in Quebec (5.5-7.8 $\mu \mathrm{g} / \mathrm{g}$ DW, Dumontet et al., 1990) and several times as high as peats affected by a Cu-Ni smelter in Finland $(<2 \mu \mathrm{g} / \mathrm{g}$ DW, Rausch et al., 2005).

In contrast, $\mathrm{Hg}$ and $\mathrm{Cu}$ concentrations in $\mathrm{A}$. wormskioldii fell within ranges similar to those of other peats (see Table 3). The absence of high $\mathrm{Hg}$ concentrations in $A$. wormskioldii was surprising given that piscivorous seabird colonies in polar regions today have major impacts on $\mathrm{Hg}$ levels in nearby terrestrial and freshwater ecosystems (Blais et al., 2005; Choy et al., 2010; Zheng et al., 2015). 
TABLE 3. Comparison of trace element concentrations in Northern Hemisphere ombrotrophic (rainwater-fed) peat bogs in the preindustrial era and in the guanogenic peat at the Carey Islands. Units are $\mu \mathrm{g} / \mathrm{g} \mathrm{DW}$, except for ng/g DW for $\mathrm{Hg}$. LoD $=$ limit of detection. Data shown are mean $\pm \mathrm{SD}$, except where ranges are presented.

\begin{tabular}{|c|c|c|c|c|c|c|c|}
\hline & $\mathrm{Hg}$ & $\mathrm{Cd}$ & $\mathrm{Br}$ & $\mathrm{Sr}$ & $\mathrm{Cu}$ & $\mathrm{Zn}$ & Sources \\
\hline Carey Islands & $14 \pm 5$ & $3.5 \pm 1.0$ & $85.0 \pm 16.1$ & $139 \pm 15$ & $6.5 \pm 2.4$ & $56.0 \pm 10.3$ & Present study \\
\hline Sask Lake 4, Flin Flon, Manitoba, before 1900 AD & $61 \pm 21$ & & $12.8 \pm 3.2$ & $19.1 \pm 2.7$ & $7.7 \pm 1.8$ & $14.0 \pm 8.4$ & Outridge et al., 2011 \\
\hline Hietajärvi bog, southern Finland, before 1100 AD & & $0.08 \pm 0.01$ & & & $1.3 \pm 0.2$ & $4 \pm 2$ & Rausch et al., 2005 \\
\hline Inuvik, Northwest Territories, $6250-180$ yr BP & $34 \pm 13$ & & $9.2 \pm 2.8$ & $23.5 \pm 8.4$ & $<1.5(\mathrm{LoD})$ & $1.5 \pm 1.0$ & Outridge and Sanei, 2010 \\
\hline Bathurst Island, Nunavut, 5900-800 yr BP & $28 \pm 4$ & & & & & & Givelet et al., 2004 \\
\hline \multicolumn{8}{|l|}{ Swiss Jura Mountains, before 1340 AD } \\
\hline - Étang de la Gruère & $25 \pm 4$ & & $16.3 \pm 2.8$ & & & & $\begin{array}{l}\text { Roos-Barraclough and } \\
\text { Shotyk, } 2003\end{array}$ \\
\hline - La Tourbière de Genevez & $68 \pm 15$ & & $15.6 \pm 2.9$ & & & & $\begin{array}{l}\text { Roos-Barraclough and } \\
\text { Shotyk, } 2003\end{array}$ \\
\hline Faroe Islands, before $880 \mathrm{AD}$ & & & $200-800$ & $10-60$ & & & Shotyk et al., 2005 \\
\hline Norway, 6 sites, before 1000 AD & $15 \pm 8$ & & & & & & Steinnes and Sjøbakk, 2005 \\
\hline Southern Germany, before 1440 BP & & $0.1-0.4$ & & & & & Küster and Rehfuess, 1997 \\
\hline Étang de la Gruère, Switzerland, $8030-240$ yr BP & & $0.076 \pm 0.022$ & & & $0.5-8$ & $1-30$ & Shotyk et al., 2002 \\
\hline
\end{tabular}

The lack of a seabird effect on peat $\mathrm{Cu}$ concentrations is also surprising, because $\mathrm{Cu}$ is one of the most highly concentrated elements in the tissues of modern seabirds in the NOW polynya (Campbell et al., 2005). The singular absence of a correlation between $\mathrm{Cu}$ and $\mathrm{TN}$, an indicator of the amount of guano deposition, suggests that $\mathrm{Cu}$ may not have been excreted in large quantities in the guano, possibly because of its role as an essential nutrient. However, a definitive explanation for the $\mathrm{Cu}$ finding is lacking.

For $\mathrm{Hg}$ and $\mathrm{Cd}$, their increase, or lack of increase, in Arctic marine ecosystems since the pre-industrial period is the most conservative explanation for the difference between this study and others concerning the impact of seabird guano on environmental $\mathrm{Hg}$ and Cd levels. The modern seabirds studied by Blais et al. (2005) and Choy et al. (2010), among others, feed in Arctic marine food webs that on average contain $\mathrm{Hg}$ concentrations an order of magnitude higher than in pre-industrial times (Dietz et al., 2009). This conclusion was in part based on $\mathrm{Hg}$ trends in the feathers of raptors from West Greenland (Dietz et al., 2006), showing that this region has experienced a degree of $\mathrm{Hg}$ contamination similar to that found elsewhere in the Arctic. In contrast to $\mathrm{Hg}, \mathrm{Cd}$ levels have not increased in Arctic marine animals since the pre-industrial period despite increased global emissions from industry (Outridge et al., 1997, 2005; AMAP, 2005). Unlike Hg, Cd is bio-diluted (i.e., decreases or is stable with increasing trophic position) in marine food webs, including that of the NOW polynya (Campbell et al., 2005). Naturally high Cd concentrations occur in zooplankton, particularly the amphipod Themisto libellula, in the NOW marine food web. Thus, the amounts of $\mathrm{Cd}$ in the mid-Holocene seabird guano may have been similar to those of the modern period, whereas $\mathrm{Hg}$ is likely to have been an order of magnitude lower. This pattern could explain why the Holocene seabirds, like seabirds today (e.g., Brimble et al., 2009b), delivered significant quantities of $\mathrm{Cd}$ to areas around the colony, but negligible amounts of $\mathrm{Hg}$.

In the absence of definitive evidence, the identity of the seabird in question remains unknown but may be constrained by currently available information. The position of the colony, on a rocky plateau above high cliffs on a small offshore island, is consistent with Atlantic Puffins (Bennike et al., 2008) or with Dovekies, which usually nest in crevices on talus slopes up to $400 \mathrm{~m}$ above sea level and are currently the most common colony-nesting seabird in the region (Montevecchi and Stenhouse, 2002). The site would be an unusual nesting location for other Arctic-nesting seabirds such as Thick-billed Murres (Uria lomvia), Northern Fulmars (Fulmarus glacialis), Black-legged Kittiwakes (Rissa tridactyla), and Glaucous Gulls (Larus hyperboreus), which are typically found in large colonies on steep cliff faces. Black Guillemot (Cepphus grylle) breeds in solitary pairs or in small groups near sea level. Puffins and Dovekies are distinguished from each other by their feeding preferences, mainly fish and zooplankton, respectively (Lowther et al., 2002; Montevecchi and Stenhouse, 2002). If the calculation above of the birds' average tissue $\delta^{15} \mathrm{~N}$ of $\geq 15.7 \%$, based on its guano $\delta^{15} \mathrm{~N}$ values, is approximately correct, then the species was predominantly a fisheater. Dovekies in the NOW ecosystem today, on the other hand, are distinguished from other seabirds by a relatively low tissue $\delta^{15} \mathrm{~N}$ of $\sim 11 \%$ (Campbell et al., 2005). Thus, it can be inferred that puffins were the species most likely to have formed the colony.

\section{ACKNOWLEDGEMENTS}

We thank David Fisher for access to ice core temperature data and Keith Hobson and Claudio Zaccone for comments on an earlier draft. Isotope analyses were performed at the Environmental Isotope Laboratory, University of Waterloo, Ontario, while elemental analyses were performed at the University of Heidelberg by M.E. Goodsite and N. Rausch. Funding for field work and studies were provided by the Danish Cooperation for Environment in the Arctic (DANCEA) grant: "Long term records of atmospheric deposition of $\mathrm{Hg}, \mathrm{Cd}, \mathrm{Pb}$ and Persistent Organic Pollutants (POPs) in peat cores from Arctic bogs (Carey Islands, Greenland and Faroe Islands) 123/000-0162" 
to M.E. Goodsite. Financial support to M.E. Goodsite and W. Shotyk was also provided by the University of Heidelberg. This manuscript was prepared in part while P.M. Outridge was a Visiting Professor at AU Herning, Aarhus University, Denmark.

\section{APPENDIX 1}

The following figure is available as a supplementary file to the online version of this article at: http://arctic. journalhosting.ucalgary.ca/arctic/index.php/arctic/rt/ suppFiles $/ 4577 / 0$

FIG. S1. Interpolated dates from ${ }^{14} \mathrm{C}$ age dating of Carey Islands peat core. (Regression equation: Calibrated date ( $\mathrm{yr}$ BP) $=4.9 \times 10^{3}+16.1 *$ Depth $-2.72 \times 10^{-2} *(\text { Depth })^{2} ; \mathrm{r}^{2}$ $=0.981, p<0.001$. Dashed lines represent $95 \%$ confidence intervals.)

\section{REFERENCES}

AMAP (Arctic Monitoring and Assessment Programme). 2005. AMAP Assessment 2002: Heavy metals in the Arctic. Oslo: AMAP. 265 p.

2011. AMAP Assessment 2011: Mercury in the Arctic. Oslo: AMAP. 193 p.

Agren, G.I., Bosatta, E., and Balesdent, J. 1996. Isotope discrimination during decomposition of organic matter: A theoretical analysis. Soil Science Society of America Journal 60(4):1121-1126.

http://dx.doi.org/10.2136/sssaj1996.03615995006000040023x

Bailey, J.N.-L., Macdonald, R.W., Sanei, H., Outridge, P.M., Johannessen, S.C., Hochheim, K., Barber, D., and Stern, G.A. 2013. Change at the margin of the North Water Polynya, Baffin Bay, inferred from organic matter records in dated sediment cores. Marine Geology 341(1):1-13.

http://dx.doi.org/10.1016/j.margeo.2013.04.017

Bauch, D., Carstens, J., Wefer, G., and Thiede, J. 2000. The imprint of anthropogenic $\mathrm{CO}_{2}$ in the Arctic Ocean: Evidence from planktonic $\delta^{13} \mathrm{C}$ data from water column and sediment surfaces. Deep Sea Research Part II 47(9-11):1791 - 1808. http://dx.doi.org/10.1016/S0967-0645(00)00007-2

Bauch, D., Erlenkeuser, H., Winckler, G., Pavlova, G., and Thiede, J. 2002. Carbon isotopes and habitat of polar planktonic foraminifera in the Okhotsk Sea: The 'carbonate ion effect' under natural conditions. Marine Micropaleontology 45: 83-99.

http://dx.doi.org/10.1016/S0377-8398(02)00038-5

Bennike, O., Goodsite, M., and Heinmeier, J. 2008. Palaeoecology of Holocene peat deposits from Nordvestø, north-west Greenland. Journal of Paleolimnology 40(1):557-565.

http://dx.doi.org/10.1007/s10933-007-9181-3

Blais, J.M., Kimpe, L.E., McMahon, D., Keatley, B.E., Mallory, M.L., Douglas, M.S.V., and Smol, J.P. 2005. Arctic seabirds transport marine-derived contaminants. Science 309(5733):445. http://dx.doi.org/10.1126/science. 1112658
Blake, W., Jr. 1991. Ratios of stable carbon isotopes in some High Arctic plants and lake sediments. Journal of Paleolimnology 6(2):157- 166 . http://dx.doi.org/10.1007/BF00153739

Bocherens, H., Billiou, D., Patou-Mathis, M., Bonjean, D., Otte, M., and Mariotti, A. 1997. Paleobiological implications of the isotopic signatures $\left({ }^{13} \mathrm{C},{ }^{15} \mathrm{~N}\right)$ of fossil mammal collagen in Scladina Cave (Sclayn, Belgium). Quaternary Research 48(3):370-380.

http://dx.doi.org/10.1006/qres.1997.1927

Bocherens, H., Hofman-Kamińska, E., Drucker, D.G., Schmölcke, U., and Kowalczyk, R. 2015. European bison as a refugee species? Evidence from isotopic data on early Holocene bison and other large herbivores in northern Europe. PLoS ONE 19(2): 30115090.

http://dx.doi.org/10.1371/journal.pone.0115090

Bradstreet, M.S.W., and Brown, R.G.B. 1985. Feeding ecology of the Atlantic Alcidae. In: Nettleship, D.N., and Birkhead, T.R., eds. The Atlantic Alcidae: The evolution, distribution and biology of the Auks inhabiting the Atlantic Ocean and adjacent water areas. London: Academic Press. 263-318.

Brassard, G.R., and Blake, W., Jr. 1978. An extensive subfossil deposit of the Arctic moss Aplodon wormskioldii. Canadian Journal of Botany 56(16):1852-1859.

http://dx.doi.org/10.1139/b78-224

Brimble, S.K., Blais, J.M., Kimpe, L.E., Mallory, M.L., Keatley, B.E., Douglas, M.S.V., and Smol, J.P. 2009a. Bioenrichment of trace elements in a series of ponds near a Northern Fulmar (Fulmarus glacialis) colony at Cape Vera, Devon Island. Canadian Journal of Fisheries and Aquatic Sciences 66(6):949-958.

http://dx.doi.org/10.1139/F09-053

Brimble, S.K., Foster, K.L., Mallory, M.L., Macdonald, R.W., Smol, J.P., and Blais, J.M. 2009b. High Arctic ponds receiving biotransported nutrients from a nearby seabird colony are also subject to potentially toxic loadings of arsenic, cadmium and zinc. Environmental Toxicology and Chemistry 28(11):2426-2433.

http://dx.doi.org/10.1897/09-235.1

Burnham, J.L., and Burnham, K.K. 2010. An ornithological survey of the Carey Islands, Northwest Greenland. Dansk Ornitologisk Forenings Tidsskrift 104:26-37.

Campbell, L.M., Norstrom, R.J., Hobson, K.A., Muir, D.C.G., Backus, S., and Fisk, A.T. 2005. Mercury and other trace elements in a pelagic Arctic marine food web (Northwater Polynya, Baffin Bay). Science of the Total Environment 351352:247-263.

http://dx.doi.org/10.1016/j.scitotenv.2005.02.043

Cherbukin, A.K., and Shotyk, W. 1996. An Energy-dispersive Miniprobe Multielement Analyzer (EMMA) for direct analysis of $\mathrm{Pb}$ and other trace elements in peats. Fresenius Journal of Analytical Chemistry 354:688-691.

Choy, E.S., Gauthier, M., Mallory, M.L., Smol, J.P., Douglas, M.S.V., Lean, D., and Blais, J.M. 2010. An isotopic investigation of mercury accumulation in terrestrial food webs adjacent to an Arctic seabird colony. Science of the Total Environment 408(8):1858- 1867.

http://dx.doi.org/10.1016/j.scitotenv.2010.01.014 
ClimaTemps. 2015. Average temperatures in Pituffik/Thule Air Base, Greenland. http://www.pituffik.climatemps.com/temperatures.php

Cocks, M.P., Balfour, D.A., and Stock, W.D. 1998. On the uptake of ornithogenic products by plants on the inland mountains of Dronning Maud Land, Antarctica, using stable isotopes. Polar Biology 20(2):107-111. http://dx.doi.org/10.1007/s003000050283

Cullen, J.T., and Maldonado, M.T. 2013. Chapter 2. Biogeochemistry of cadmium and its release to the environment. In: Sigel, A., Sigel, H., and Sigel, R.K.O., eds. Cadmium: From toxicity to essentiality. Metal Ions in Life Sciences 11. Dordrecht: Springer. 31-62. http://dx.doi.org/10.1007/978-94-007-5179-8_2

Dietz, R., Riget, F.F., Boertmann, D., Sonne, C., Olsen, M.T., Fjeldså, J., Falk, K., et al. 2006. Time trends of mercury in feathers of West Greenland birds of prey during 1851-2003. Environmental Science and Technology 40(19):5911 -5916. http://dx.doi.org/10.1021/es0609856

Dietz, R., Outridge, P.M., and Hobson, K.A. 2009. Anthropogenic contributions to mercury levels in present-day Arctic animals-A review. Science of the Total Environment 407(24):6120-6131. http://dx.doi.org/10.1016/j.scitotenv.2009.08.036

Disnar, J.-R., Jacob, J., Morched-Issa, M., Lottier, N., and Arnaud, F. 2008. Assessment of peat quality by molecular and bulk geochemical analysis: Application to the Holocene record of the Chautagne marsh (Haute Savoie, France). Chemical Geology 254(1-2):101-112. http://dx.doi.org/10.1016/j.chemgeo.2008.06.004

Dumontet, S., Lévesque, M., and Mathur, S.P. 1990. Limited downward migration of pollutant metals $(\mathrm{Cu}, \mathrm{Zn}, \mathrm{Ni}$, and $\mathrm{Pb})$ in acidic virgin peat soils near a smelter. Water, Air and Soil Pollution 49(3):329-342. http://dx.doi.org/10.1007/BF00507072

Dyke, A.S., England, J., Reimnitz, E., and Jetté, H. 1997. Changes in driftwood delivery to the Canadian Arctic Archipelago: The hypothesis of postglacial oscillations of the Transpolar Drift. Arctic 50(1):1-16. http://dx.doi.org/10.14430/arctic1086

Esmeijer-Liu, A.J., Kürschner, W.M., Lotter, A.F., Verhoeven, J.T.A., and Goslar, T. 2012. Stable carbon and nitrogen isotopes in a peat profile are influenced by early stage diagenesis and changes in atmospheric $\mathrm{CO}_{2}$ and $\mathrm{N}$ deposition. Water, Air \& Soil Pollution 223(5):2007-2022. http://dx.doi.org/10.1007/s11270-011-1001-8

Foster, K.L., Kimpe, L.E., Brimble, S.K., Liu, H., Mallory, M.L., Smol, J.P., Macdonald, R.W., and Blais, J.M. 2011. Effects of seabird vectors on the fate, partitioning, and signatures of contaminants in a High Arctic ecosystem. Environmental Science \& Technology 45(23):10053 - 10060. http://dx.doi.org/10.1021/es202754h

Gajewski, K. 2015. Quantitative reconstruction of Holocene temperatures across the Canadian Arctic and Greenland. Global and Planetary Change 128:14-23. http://dx.doi.org/10.1016/j.gloplacha.2015.02.003
Givelet, N., Roos-Barraclough, F., Goodsite, M.E., Cheburkin, A.K., and Shotyk, W. 2004. Atmospheric mercury accumulation rates between 5900 and 800 calibrated years BP in the High Arctic of Canada recorded by peat hummocks. Environmental Science \& Technology 38(19):4964-4972. http://dx.doi.org/10.1021/es0352931

Godzik, B. 1991. Heavy metals and macroelements in the tundra of southern Spitsbergen: The effect of Little Auk Alle alle (L.) colonies. Polar Research 9(2):121-131.

http://dx.doi.org/10.1111/j.1751-8369.1991.tb00608.x

Hamel, D., de Vernal, A., Gosselin, M., and Hillaire-Marcel, C. 2002. Organic-walled microfossils and geochemical tracers: Sedimentary indicators of productivity changes in the North Water and northern Baffin Bay during the last centuries. Deep Sea Research Part II 49(22-23):5277-5295. http://dx.doi.org/10.1016/S0967-0645(02)00190-X

Hobson, K.A. 2005. Tracing contaminants with $\delta^{15} \mathrm{~N}$ measurements. Science 310(5747):443.

Hobson, K.A., Piatt, J.F., and Pitocchelli, J. 1994. Using stable isotopes to determine seabird trophic relationships. Journal of Animal Ecology 63(4):786-798. http://dx.doi.org/10.2307/5256

Hobson, K.A., Fisk, A., Karnovsky, N., Holst, M., Gagnon, J.M., and Fortier, M. 2002. A stable isotope $\left(\delta^{13} \mathrm{C}, \delta^{15} \mathrm{~N}\right)$ model for the North Water food web: Implications for evaluating trophodynamics and the flow of energy and contaminants. Deep Sea Research Part II 49(22-23):5131 - 5150. http://dx.doi.org/10.1016/S0967-0645(02)00182-0

Keeling, C.D. 1979. The Suess effect: ${ }^{13}$ Carbon $-{ }^{14}$ Carbon interrelations. Environment International 2(4-6):229-300. http://dx.doi.org/10.1016/0160-4120(79)90005-9

Koch, P.L. 1998. Isotopic reconstruction of past continental environments. Annual Review of Earth and Planetary Sciences 26:573-613. http://dx.doi.org/10.1146/annurev.earth.26.1.573

Kristensen, D.K., Kristensen, E., Forchhammer, M.C., Michelsen, A., and Schmidt, N.M. 2011. Arctic herbivore diet can be inferred from stable carbon and nitrogen isotopes in $\mathrm{C}_{3}$ plants, faeces, and wool. Canadian Journal of Zoology 89(10):892 - 899. http://dx.doi.org/10.1139/z11-073

Küster, H., and Rehfuess, K.-E. 1997. Pb and Cd concentrations in a southern Bavarian bog profile and the history of vegetation as recorded by pollen analysis. Water, Air \& Soil Pollution 100(3):379-386. http://dx.doi.org/10.1023/A:1018328626823

Kuhry, P., and Vitt, D.H. 1996. Fossil carbon/nitrogen ratios as a measure of peat decomposition. Ecology 77(1):271 - 275. http://dx.doi.org/10.2307/2265676

Levac, E., de Vernal, A., and Blake, W., Jr. 2001. Sea-surface conditions in northernmost Baffin Bay during the Holocene: Palynological evidence. Journal of Quaternary Science 16(4):353-363. http://dx.doi.org/10.1002/jqs.614

Lowther, P.E., Diamond, A.W., Kress, S.W., Robertson, G.R., and Russell, K. 2002. Atlantic Puffin (Fratercula arctica). In: Poole, A., ed. The birds of North America Online. Ithaca, New York: Cornell Lab of Ornithology. http://dx.doi.org/10.2173/bna.709 
Meyers, P.A. 1994. Preservation of elemental and isotopic source identification of sedimentary organic matter. Chemical Geology 114(3-4):289-302.

http://dx.doi.org/10.1016/0009-2541(94)90059-0

Mizutani, H., Hasegawa, H., and Wada, E. 1986. High nitrogen isotope ratio for soils of seabird rookeries. Biogeochemistry 2(3): $221-247$.

http://dx.doi.org/10.1007/BF02180160

Montevecchi, W.A., and Stenhouse, I.J. 2002. Dovekie (Alle alle). In: Poole, A., ed. The birds of North America Online. Ithaca, New York: Cornell Lab of Ornithology. http://dx.doi.org/10.2173/bna.701

Nie, Y., Liu, X., Sun, L., and Emslie, S.D. 2012. Effect of penguin and seal excrement on mercury distribution in sediments from the Ross Sea region, East Antarctica. Science of the Total Environment 433:132-140.

http://dx.doi.org/10.1016/j.scitotenv.2012.06.022

Nørnberg, T., Goodsite, M.E., and Shotyk, W. 2004. An improved motorized corer and sample processing system for frozen peat. Arctic 57(3):242-246.

http://dx.doi.org/10.14430/arctic501

Outridge, P.M., and Sanei, H. 2010. Does organic matter degradation affect the reconstruction of pre-industrial atmospheric mercury deposition rates from peat cores? - A test of the hypothesis using a permafrost peat deposit in northern Canada. International Journal of Coal Geology 83(1):73-81. http://dx.doi.org/10.1016/j.coal.2010.04.004

Outridge, P.M., Evans, R.D., Wagemann, R., and Stewart, R.E.A. 1997. Historical trends of heavy metals and stable lead isotopes in beluga (Delphinapterus leucas) and walrus (Odobenus rosmarus rosmarus) in the Canadian Arctic. Science of the Total Environment 203(3):209-219. http://dx.doi.org/10.1016/S0048-9697(97)00142-3

Outridge, P.M., Hobson, K.A., and Savelle, J.M. 2005. Changes in mercury and cadmium concentrations and the feeding behaviour of beluga (Delphinapterus leucas) near Somerset Island, Canada, during the 20th century. Science of the Total Environment 350(1-3):106-118.

http://dx.doi.org/10.1016/j.scitotenv.2004.12.081

___ 2009. Long-term changes of mercury levels in ringed seal (Phoca hispida) from Amundsen Gulf, and beluga (Delphinapterus leucas) from the Beaufort Sea, western Canadian Arctic. Science of the Total Environment 407(23):6044-6051.

http://dx.doi.org/10.1016/j.scitotenv.2009.08.018

Outridge, P.M., Rausch, N., Percival, J.B., Shotyk, W., and McNeely, R. 2011. Comparison of mercury and zinc profiles in peat and lake sediment archives with historical changes in emissions from the Flin Flon metal smelter, Manitoba, Canada. Science of the Total Environment 409(3):548-563. http://dx.doi.org/10.1016/j.scitotenv.2010.10.041

Peterson, B.J., and Fry, B. 1987. Stable isotopes in ecosystem studies. Annual Review of Ecology and Systematics 18:293-320.

http://dx.doi.org/10.1146/annurev.es.18.110187.001453
Rausch, N., Nieminen, T., Ukonmaanaho, L., Le Roux, G., Krachler, M., Cheburkin, A., Bonani, G., and Shotyk, W. 2005. Comparison of atmospheric deposition of copper, nickel, cobalt, zinc, and cadmium recorded by Finnish peat cores with monitoring data and emission records. Environmental Science \& Technology 39(16):5989-5998. http://dx.doi.org/10.1021/es050260m

Robinson, D. 2001. $\delta^{15} \mathrm{~N}$ as an integrator of the nitrogen cycle. Trends in Ecology \& Evolution 16(3):153-162.

http://dx.doi.org/10.1016/S0169-5347(00)02098-X

Roos-Barraclough, F., and Shotyk, W. 2003. Millennial-scale records of atmospheric mercury deposition obtained from ombrotrophic and minerotrophic peatlands in the Swiss Jura Mountains. Environmental Science \& Technology 37(2):235-244.

http://dx.doi.org/10.1021/es0201496

Schubert, C.J., and Calvert, S.E. 2001. Nitrogen and carbon isotopic composition of marine and terrestrial organic matter in Arctic Ocean sediments: Implications for nutrient utilization and organic matter composition. Deep Sea Research Part I 48(3):789-810.

http://dx.doi.org/10.1016/S0967-0637(00)00069-8

Sharma, S., Mora, G., Johnston, J.W., and Thompson, T.A. 2005. Stable isotope ratios in swale sequences of Lake Superior as indicators of climate and lake level fluctuations during the Late Holocene. Quaternary Science Reviews 24(16-17):1941 - 1951. http://dx.doi.org/10.1016/j.quascirev.2004.11.009

Shotyk, W., Blaser, P., Grünig, A., and Cheburkin, A.K. 2000. A new approach for quantifying cumulative, anthropogenic, atmospheric lead deposition using peat cores from bogs: $\mathrm{Pb}$ in eight Swiss peat bog profiles. Science of the Total Environment 249(1-3):281-295.

http://dx.doi.org/10.1016/S0048-9697(99)00523-9

Shotyk, W., Krachler, M., Martinez-Cortizas, A., Cheburkin, A.K., and Emons, H. 2002. A peat bog record of natural, preanthropogenic enrichments of trace elements in atmospheric aerosols since $12370{ }^{14} \mathrm{C}$ yr BP, and their variation with Holocene climate change. Earth and Planetary Science Letters 199(1-2):21-37. http://dx.doi.org/10.1016/S0012-821X(02)00553-8

Shotyk, W., Goodsite, M.E., Roos-Barraclough, F., Givelet, N., Le Roux, G., Weiss, D., Cheburkin, A.K., et al. 2005. Accumulation rates and predominant atmospheric sources of natural and anthropogenic $\mathrm{Hg}$ and $\mathrm{Pb}$ on the Faroe Islands. Geochimica et Cosmochimica Acta 69(1):1-17. http://dx.doi.org/10.1016/j.gca.2004.06.011

Sokal, R.R., and Rohlf, F.J. 1981. Biometry, 2nd ed. San Francisco: W.H. Freeman and Co.

Steere, W.C. 1973. Observations on the genus Aplodon (Musci: Splachnaceae). The Bryologist 76(3):347-355. http://dx.doi.org/10.2307/3241716

Steinnes, E., and Sjøbakk, T.E. 2005. Order-of-magnitude increase of $\mathrm{Hg}$ in Norwegian peat profiles since the outset of industrial activity in Europe. Environmental Pollution 137(2):365-370. http://dx.doi.org/10.1016/j.envpol.2004.10.008 
Stempniewicz, L., Błachowiak-Samołyk, K., and Węsławski, J.M. 2007. Impact of climate change on zooplankton communities, seabird populations and Arctic terrestrial ecosystem-A scenario. Deep Sea Research Part II 54(23-26):2934-2945. http://dx.doi.org/10.1016/j.dsr2.2007.08.012

Sunderland, E.M., and Mason, R.P. 2007. Human impacts on open ocean mercury concentrations. Global Biogeochemical Cycles 21(4), GB4022.

http://dx.doi.org/10.1029/2006GB002876

Tillman, P.K., Holzkämper, S., Kuhry, P., Sannel, A.B.K., Loader, N.J., and Robertson, I. 2010. Stable carbon and oxygen isotopes in Sphagnum fuscum peat from subarctic Canada: Implications for palaeoclimate studies. Chemical Geology 270(1-4):216-226.

http://dx.doi.org/10.1016/j.chemgeo.2009.12.001

Tremblay, J.-É., Hattori, H., Michel, C., Ringuette, M., Mei, Z.-P., Lovejoy, C., Fortier, L., Hobson, K.A., Amiel, D., and Cochran, K. 2006. Trophic structure and pathways of biogenic carbon flow in the eastern North Water Polynya. Progress in Oceanography 71(2-4):402-425.

http://dx.doi.org/10.1016/j.pocean.2006.10.006

UNEP (United Nations Environment Programme). 2010. Final review of scientific information on cadmium. Geneva: UNEP, Chemical Branch. 324 p.

http://www.unep.org/chemicalsandwaste/Portals/9/Lead_ Cadmium/docs/Interim_reviews/UNEP_GC26_INF_11_ Add_2_Final_UNEP_Cadmium_review_and_apppendix_ Dec_2010.pdf.
Vinther, B.M., Buchardt, S.L., Clausen, H.B., Dahl-Jensen, D., Johnsen, S.J., Fisher, D.A., Koerner, R.M., et al. 2009. Holocene thinning of the Greenland ice sheet. Nature 461:385-388. http://dx.doi.org/10.1038/nature08355

Wainwright, S.C., Haney, J.C., Kerr, C., Golovkin, A.N., and Flint, M.V. 1998. Utilization of nitrogen derived from seabird guano by terrestrial and marine plants at St. Paul, Pribilof Islands, Bering Sea, Alaska. Marine Biology 131(1):63-71.

http://dx.doi.org/10.1007/s002270050297

Zaccone, C., Casiello, G., Longobardi, F., Bragazza, L., Sacco, A., and Miano, T.M. 2011. Evaluating the 'conservative' behavior of stable isotopic ratios $\left(\delta^{13} \mathrm{C}, \delta^{15} \mathrm{~N}\right.$, and $\left.\delta^{18} \mathrm{O}\right)$ in humic acids and their reliability as paleoenvironmental proxies along a peat sequence. Chemical Geology 285(1-4):124-132. http://dx.doi.org/10.1016/j.chemgeo.2011.03.018

Zhao, F.-J., Spiro, B., and McGrath, S.P. 2001. Trends in ${ }^{13} \mathrm{C} / 12 \mathrm{C}$ ratios and $\mathrm{C}$ isotope discrimination of wheat since 1845 . Oecologia 128(3):336-342. http://dx.doi.org/10.1007/s004420100663

Zheng, W., Xie, Z., and Bergquist, B.A. 2015. Mercury stable isotopes in ornithogenic deposits as tracers of historical cycling of mercury in Ross Sea, Antarctica. Environmental Science \& Technology 49(13):7623-7632.

http://dx.doi.org/10.1021/acs.est.5b00523 